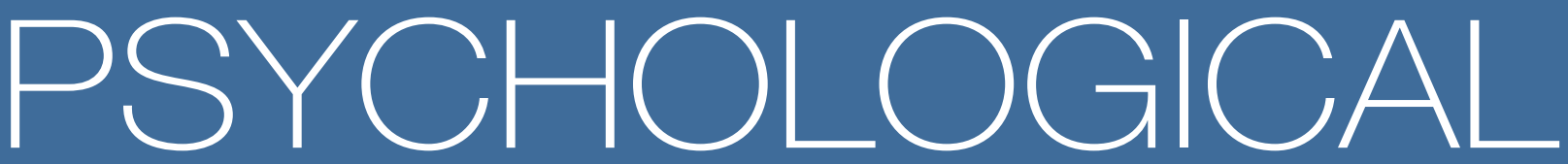

MEDICINE

A Journal for Research in Psychiatry

and the Allied Sciences

Editors

Kenneth S. Kendler \& Robin M. Murray

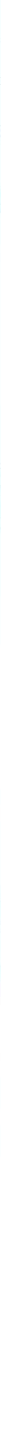




\title{
EDITORIAL COMMITTEE
}

\author{
Editors \\ Kenneth S Kendler, Department of Psychiatry, Virginia Commonwealth University \\ ROBIN M MURRAY, Institute of Psychiatry, Kings College, London \\ Associate Editors \\ TS BRUGHA, Department of Health Sciences, University of Leicester \\ R. KEEFE, Duke University Medical Center, Durham, NC \\ CM PARIANTE, Institute of Psychiatry, Kings College, London \\ D. PINE, NIMH, DIRP, Bethesda \\ BaRBara SAHAKIAN, Department of Psychiatry, University of Cambridge
}

Technical Editor SJ PARR

EDITORIAL BOARD

\author{
AC ANGOLD, Durham, NC \\ $\mathrm{P}$ BECH, Hillerød \\ A BERTOLINO, Bari \\ D BLAZER, Durham, NC \\ n BReslau, Michigan \\ EJ BROMET, NeW York \\ A CASPI, Durham \\ PJ COWEN, OXford \\ CV DOLAN, Amsterdam \\ A EHLERS, London \\ ac frazier-WOOd, Houston TX \\ CD FRITH, London \\ M GILL, Dublin \\ D GOLDBERG, London \\ J HALL, Edinburgh \\ PJ HARRISON, Oxford
}

\author{
M HOTOPF, London \\ aV JABlensky, Perth \\ E JOYCE, London \\ R KESSLER, Boston \\ KL KLUMP, Michigan \\ L KRABBendam, Maastricht \\ J LEVENSON, Richmond \\ P McGUIRE, London \\ P McKENNA, Barcelona \\ A MEYER-Lindenberg, Mannheim \\ J MIETTUNEN, OUlu \\ C MORGAN, London \\ EK MOSCICKI, Arlington \\ K NUEChterLein, Los Angeles \\ D pizzagalli, Cambridge, MA \\ tW RobBins, Cambridge
}

\author{
M RUGGERI, Verona \\ AJ RUSH, Dallas \\ ML RUTTER, London \\ U SCHMIDT, London \\ J-P SELTEN, Maastricht, Netherlands \\ M SHARPE, Edinburgh \\ M STEIN, San Diego \\ PF sullivan, Chapel Hill, NC \\ N TAKEI, Hamamatsu \\ N VAN HAREN, Utrecht \\ J VAN OS, Maastricht \\ H VERDOUX, Bordeaux \\ MM WEISSMAN, NeW York \\ S WESSELY, London
}

\section{Editor Emeritus EUGENE PAYKEL}

Psychological Medicine is a journal primarily for the publication of original research in clinical psychiatry and the basic sciences related to it. These include relevant fields of biological enquiry traditionally associated with medicine but also the various psychological and social sciences. Review articles, editorials and letters to the Editor discussing published papers are also published. Contributions must be in English.

Books for review should be sent to one of the two Editors, depending on country of publication (see instructions for contributors).

\section{(c) Cambridge University Press 2013}

COPYING This journal is registered with the Copyright Clearance Center, 222 Rosewood Drive, Danvers, MA 01923. Organizations in the USA who are also registered with C.C.C. may therefore copy material (beyond the limits permitted by sections 107 and 108 of US copyright law) subject to payment to C.C.C. of the per-copy fee of $\$ 16.00$. This consent does not extend to multiple copying for promotional or commercial purposes. Code 0033-2917/2013 \$16.00. Organizations authorized by the Copyright Licensing Agency may also copy material subject to the usual conditions. ISI Tear Sheet Service, 3501 Market Street, Philadelphia, Pennsylvania 19104, USA, is authorized to supply single copies of separate articles for private use only. For all other use, permission should be sought from Cambridge or the American Branch of Cambridge University Press.

SUBSCRIPTIONs Psychological Medicine (ISSN 0033-2917) is published monthly by Cambridge University Press, The Edinburgh Building, Shaftesbury Road, Cambridge CB2 8RU, UK/Cambridge University Press, 32 Avenue of the Americas, New York, NY 10013-2473, USA. The subscription price (excluding VAT), which includes print and electronic access, of volume 43, 2013 is £909 (US \$1683 in USA, Canada and Mexico) for institutions; £342 (US \$426 in USA, Canada and Mexico) for individuals ordering direct from the Press and certifying that the journal is for their personal use. The electronic-only price available to institutional subscribers is £667 (US \$1234 in USA, Canada and Mexico). Twelve parts form a volume. Single parts cost £76 (US \$141 in USA, Canada and Mexico) plus postage. EU subscribers (outside the UK) who are not registered for VAT should add VAT at their country's rate. VAT registered subscribers should provide their VAT registration number. Orders, which must be accompanied by payment, may be sent to any bookseller or subscription agent or direct to the publishers: Cambridge University Press, The Edinburgh Building, Shaftesbury Road, Cambridge CB2 8RU, UK, or in the USA, Canada and Mexico, to Cambridge University Press, Journals Fulfillment Department, 100 Brook Hill Drive, West Nyack, New York 10994-2133. Japanese prices for institutions are available from Kinokuniya Company Ltd, P.O. Box 55, Chitose, Tokyo 156, Japan.

Periodicals postage paid at New York, NY, and at additional mailing offices. POSTMASTER: send address changes in the USA, Canada and Mexico to Psychological Medicine, Cambridge University Press, 100 Brook Hill Drive, West Nyack, New York 10994-2133.

Claims for missing issues will not be entertained unless made immediately upon receipt of the subsequent issue.

INTERNET ACCESS This journal is included in the Cambridge Journals Online service which can be found at http://journals.cambridge.org/. For further information on other Press titles access http://www.cambridge.org/.

Enquiries about advertising should be sent to the Journal's Promotion Department of the Cambridge or American Branch of Cambridge University Press.

This journal issue has been printed on FSC-certified paper and cover board. FSC is an independent, non-governmental, not-for-profit organization established to promote the responsible management of the world's forests. Please see www.fsc.org for information. 